\title{
PFPRINTE

\section{5) Envelhecimento feminino e trabalho: relatos de moradores idosos da Mooca e do Brás (São Paulo/ SP)}

\author{
Lucila Maria Barbosa Egydio'; Maria Luisa Trindade Bestetti²; \\ Marisa Accioly Domingues²; Bibiana Graeff ${ }^{2}$
}

\section{Resumo}

De 2015 a 2018, o método "Cidade Amiga do Idoso" (WHO, 2007) foi adaptado e aplicado aos bairros Brás e Mooca, em São Paulo. Em um recorte analítico, a presente pesquisa buscou identificar e discutir, por meio da Análise de Conteúdo (BARDIN, 2010), as questões de gênero ligadas ao envelhecimento feminino mais frequentemente evocadas em 10 grupos focais com moradores idosos: 4 com pessoas entre 60 e 75 anos de idade e 4 com pessoas com 76 anos ou mais de idade, além de 2 grupos mistos, num total de 37 mulheres e 22 homens. O trabalho foi a principal temática abordada relacionando questões de gênero e envelhecimento feminino. As subcategorias temáticas foram: a) papel social e trabalho; b) submissão de esposas ao marido; 3) empoderamento feminino e trabalho; 4) fragilidades físicas e atuação profissional e 5) trabalho voluntário. Como consequência da maior presença da mulher no mercado de trabalho, fica evidente que a percepção de perda de papel social com a chegada da aposentadoria, antes mais evidente nos homens, começa a ser manifestada também por mulheres. Estas seguem buscando fazer da velhice uma etapa significativa de suas vidas; mais do que para os homens, o trabalho voluntário aparece para elas como uma possibilidade de participação. Quanto ao trabalho remunerado, o ageismo foi relatado tanto idosas, quanto por idosos. A realização de trabalhos domésticos foi mais comum entre as participantes.

Palavras chave: envelhecimento ativo - mulheres idosas - trabalho.

1 Mestranda no Programa de Pós-Graduação em Gerontologia da Universidade de São Paulo (USP), Escola de Artes, Ciências e Humanidades (EACH). Endereço para correspondência: R. Arlindo Béttio, 1000, Ermelino Matarazzo São Paulo - SP, Brasil. CEP: 03828-000. E-mail: lucila_egydio@usp.br

2 Professoras no Programa de Pós-Graduação em Gerontologia da Universidade de São Paulo (USP), Escola de Artes, Ciências e Humanidades (EACH). E-mails (na ordem em que aparecem): maria.luisa@usp.br; maccioly@usp.br; bibiana.graeff@usp.br 


\section{Female Aging and Work: reports of elderly residents of Mooca and Brás (São Paulo /SP)}

\section{Abstract}

From 2015 to 2018, the "City of the Elderly" (WHO, 2007) was adapted and applied to the Brás and Mooca neighborhoods in São Paulo. In an analytical review, the present research sought to identify and discuss, through the Content Analysis (BARDIN, 2010), the gender issues related to female aging most frequently evoked in 10 focus groups with elderly residents: 4 with people between 60 and 75 years of age and 4 with people aged 76 years and over, in addition to 2 mixed groups, in a total of 37 women and 22 men. The work was the main theme addressed relating gender issues and female aging. The thematic subcategories were: a) social role and work; b) submission of wives to the husband; 3) female empowerment and work; 4) physical weaknesses and professional performance and 5) voluntary work. As a consequence of the greater presence of women in the labor market, it is evident that the perception of loss of social role with the arrival of retirement, which is more evident in men, is also manifested by women. They continue to seek to make old age a significant step in their lives; more than for men, volunteer work appears to them as a possibility of participation. Regarding paid work, ageism was reported both in the elderly and in the elderly. Performing housework was more common among participants.

Keywords: active aging - elderly women - work. 